\title{
TURYSTYKA NA OBSZARACH CHRONIONYCH W POLSCE
}

\section{Wstęp}

Zasadniczym celem niniejszego opracowania jest wprowadzenie Czytelnika do określonej tematyki, poruszonej w odrębnym dziale tej monografii, zatytułowanym „Notatki naukowe”. Zamieszczone w tej części teksty dotyczą turystyki na obszarach chronionych jako zagadnienia badawczego oraz będącego przedmiotem nauczania studentów na pierwszym stopniu kształcenia (licencjackim) w zakresie turystyki i rekreacji na Uniwersytecie Łódzkim.

W dziale tym zawarto pięć notatek. Oprócz niniejszej, w której zostały omówione ogólne zagadnienia związane z turystyką na obszarach różnych form chronionych, cztery prace odnoszą się do następujących parków narodowych: Tatrzańskiego (dwie notatki) oraz Wigierskiego i Pienińskiego (po jednej). Teksty te zostały napisane przez studentki pierwszego roku studiów licencjackich turystyka i rekreacja na Wydziale Nauk Geograficznych Uniwersytetu Łódzkiego. W pomyśle opublikowania tych prac miał swój udział autor piszący te słowa, gdyż w 2018 r. odbywał praktyki zawodowe $\mathrm{w}$ ramach przedmiotu akademickiego o nazwie turystyczne i rekreacyjne użytkowanie obszarów chronionych. Więcej o założeniach dydaktycznych tego przedmiotu napisano w drugiej części tej notatki, w pierwszej zaś skupiono się na zdefiniowaniu obszarów chronionych oraz przedstawieniu ich relacji z ruchem turystycznym. 


\section{Obszary chronione a turystyka}

Turystyka na obszarach chronionych jest zjawiskiem bardzo złożonym i szeroko opisywanym w literaturze naukowej. Ograniczenia objętościowe niniejszej monografii pozwolą na poruszenie jedynie kilku podstawowych jego aspektów. Zagadnienie to leży w kręgu zainteresowania wielu nauk, np. geografii, przyrody, ekologii, ochrony środowiska czy prawa. Podobnie jak zróżnicowane jest środowisko przyrodnicze obszarów chronionych, również tematyka turystyki na tych terenach odnosi się do szerokiego spektrum zagadnień. W literaturze można więc doszukać się jej analizowania na wielu płaszczyznach, m.in.: społecznej, ekonomicznej, gospodarczej, a nawet architektonicznej.

Najtrudniejszym zagadnieniem w badaniach nad zjawiskiem turystyki na obszarach chronionych jest pogodzenie ze sobą dwóch przeciwstawnych funkcji takich obszarów: ochrony środowiska i zasobów przyrody oraz ich udostępniania człowiekowi do różnych celów. Jest to problem, z którym boryka się każdy obszar chroniony zarówno w Polsce, jak i na świecie. Z dylematem, jak jednocześnie skutecznie chronić obszar oraz udostępniać go turystom czy innym grupom interesariuszy, próbują sobie poradzić pracownicy różnych instytucji oraz skupione wokół nich środowiska naukowe. Opracowywane są plany oraz strategie ochrony i udostępniania konkretnych terenów, plany zagospodarowania przestrzennego itp. Widać więc, jak wiele zagadnień i problemów należy poruszyć, aby znaleźć najwłaściwsze rozwiązanie i dla przyrody, i dla człowieka. Zdaniem autora wspomniany wcześniej problem dwubiegunowości funkcji terenu chronionego: jego ochrona a użytkowanie turystyczne, wyłania się już na poziomie definiowania niektórych typów obszarów chronionych. W tym celu warto przyjrzeć się np. znaczeniu terminu „park narodowy”. W świetle Ustawy o ochronie przyrody $z$ dnia 16 kwietnia 2014 r. jest to obszar wyróżniający się szczególnymi wartościami przyrodniczymi, naukowymi, społecznymi, kulturowymi i edukacyjnymi, o powierzchni nie mniejszej niż 1000 ha, na którym ochronie podlega cała przyroda oraz walory krajobrazowe (Ustawa, 2014).

Z pierwszej części definicji wynika, że rejony, które mają zostać objęte ochroną, muszą mieć unikatowe właściwości. Można zatem uważać, że powinny to być obszary przyrodniczo cenne. Te zaś w literaturze są różnie objaśniane. Z kilku przytoczonych poniżej przykładowych definicji obszarów przyrodniczo cennych, dowiadujemy się, że: 
1) przedstawiają one wartości dane przez przyrodę, przydatne do prowadzenia jakiejkolwiek działalności ludzkiej (Radecki, 1987);

2) są to obszary lądu lub morza o wysokiej różnorodności biologicznej, a także związanych z nim zasobów naturalnych i kulturowych, zasługujących na utrzymanie $\mathrm{w}$ stanie względnie niezmienionym (Dobrzański, Dobrzyńska, Kiełczewski, 1997);

3) są to tereny, których różnorodność biologiczna i krajobrazowa stanowi lub może stanowić dominujący i istotny czynnik działalności gospodarczej lub w zasadniczy sposób ogranicza konwencjonalne formy gospodarowania (Dobrzański, Dobrzyńska, Kiełczewski, 1997).

$Z$ drugiej części definicji parku narodowego wynika natomiast, że ochronie podlega teoretycznie wszystko, co znajduje się w jego granicach. Widać więc, że już na poziomie definiowania trudno jednoznacznie określić funkcję tych obszarów. Jeszcze trudniej jest to przełożyć na praktyczne działanie. Polskie prawo precyzyjnie formułuje jednak cele powstawania parków narodowych. Są one powoływane, by chronić i zachować różnorodność środowiska przyrodniczo-kulturowego. Mają być one udostępniane w różnych celach: edukacyjnych, kulturowych, turystycznych, w taki sposób, który nie będzie zagrażał środowisku (Harasimiuk, Sawicki, 2014).

W niniejszych rozważaniach jako obszary chronione brane są pod uwagę następujące powierzchniowe formy ochrony przyrody: parki narodowe, parki krajobrazowe, rezerwaty przyrody i obszary Natura 2000, na których problem konfliktu turystyki i ochrony środowiska jest najbardziej widoczny. Wszelka działalność gospodarcza oraz użytkowanie tych obszarów powinny być podporządkowane ochronie zasobów przyrody, która odgrywa nadrzędną rolę.

Turystyczne użytkowanie obszarów chronionych ma swoje wady i zalety. $Z$ jednej strony wiąże się ono $\mathrm{z}$ mocną ingerencją $\mathrm{w}$ środowisko naturalne $-\mathrm{z}$ koniecznością wprowadzania specjalnej infrastruktury oraz wytyczenia tras, po których będą poruszali się turyści (w celu ograniczenia ich ekspansji na cały obszar). Z drugiej strony ruch turystyczny jest źródłem wielu czynników negatywnie wpływających na środowisko, takich jak np.: niszczenie szaty roślinnej, śmiecenie, hałasowanie. To tylko kilka z wielu przykładów niekorzystnego wpływu ruchu turystycznego na przyrodę.

Uprawianie turystyki przynosi także wiele pozytywnych efektów. Pojawienie się jej na terenach przyrodniczo cennych skutkuje wdrożeniem działań ochronnych. Wiele obszarów chronionych powołano w momencie, gdy zaczęli je licznie odwiedzać turyści. Wydziela się wtedy strefy, 
w których mogą oni przebywać, oraz takie, w których znajdować im się nie wolno, ponieważ chroni się tam najcenniejsze zasoby środowiska przyrodniczo-kulturowego. Turystyka ma także ważne znaczenie z punktu widzenia społeczno-ekonomicznego. Obszary chronione posiadają bowiem unikatowe walory turystyczne, dzięki którym określony teren staje się atrakcyjny turystycznie oraz spełnia kilka ważnych funkcji, tj. poznawczą, edukacyjną, zdrowotną czy rekreacyjną. Zakłada się między innymi, że podczas wizyty $\mathrm{w}$ parku czy rezerwacie $\mathrm{w}$ turyście budzi się ciekawość, chęć poznania miejsca, w którym się znajduje, a także wrażliwość i szacunek do otaczającej go przyrody. Otwiera się też przed nim - dzięki zróżnicowanym walorom środowiska - możliwość uprawiania różnych form turystyki i rekreacji. Najbardziej pożądanymi formami turystyki na obszarach chronionych są: turystyka poznawcza, krajobrazowa i ekologiczna (zielona). W literaturze można spotkać się także z pojęciem turystyki miękkiej (ang. soft tourism), która jak wcześniej wymienione formy odbywa się z uszanowaniem praw środowiska naturalnego, oddziałując na nie minimalnie. Uprawiający je turyści powinni charakteryzować się wysokim stopniem świadomości oraz wiedzy ekologicznej (Dudek, Kowalczyk, 2003).

W rzeczywistości bywa jednak różnie. Są obszary, gdzie turystyka osiągnęła już poziom masowej, zbliżającej się do poziomu alarmowego chłonności turystycznej parku narodowego i zdecydowanie odbiega od założeń turystyki ekologicznej. Generalnie liczba turystów odwiedzających parki narodowe jest jednak mocno zróżnicowana i zależy od wielu czynników. Najchętniej uczęszczanym przez zwiedzających typem obszarów chronionych są parki narodowe, gdzie otacza się ochroną najcenniejsze w skali kraju zasoby środowiska, a możliwości uprawiania turystyki i rekreacji są bardzo szerokie. Analizując ruch turystyczny w poszczególnych polskich parkach narodowych, można dostrzec znaczne dysproporcje liczby osób, które odwiedzają te obszary (rys. 1).

Za wielkość ruchu turystycznego oraz tak duże jego zróżnicowanie w poszczególnych parkach odpowiada ich atrakcyjność turystyczna, na którą składają się:

1) walory turystyczne, umożliwiające uprawianie różnych form turystyki i rekreacji;

2) zagospodarowanie turystyczne - w pobliżu niektórych parków narodowych znajdują się duże ośrodki turystyczne, oferujące szeroki zakres usług (TPN - Zakopane, KPN - Karpacz, Szklarska Poręba, WPN - Świnoujście, Międzyzdroje); 
3) dostępność komunikacyjna - do niektórych parków można dotrzeć szybko na kilka sposobów, do innych dostęp jest trudniejszy i bardziej czasochłonny.

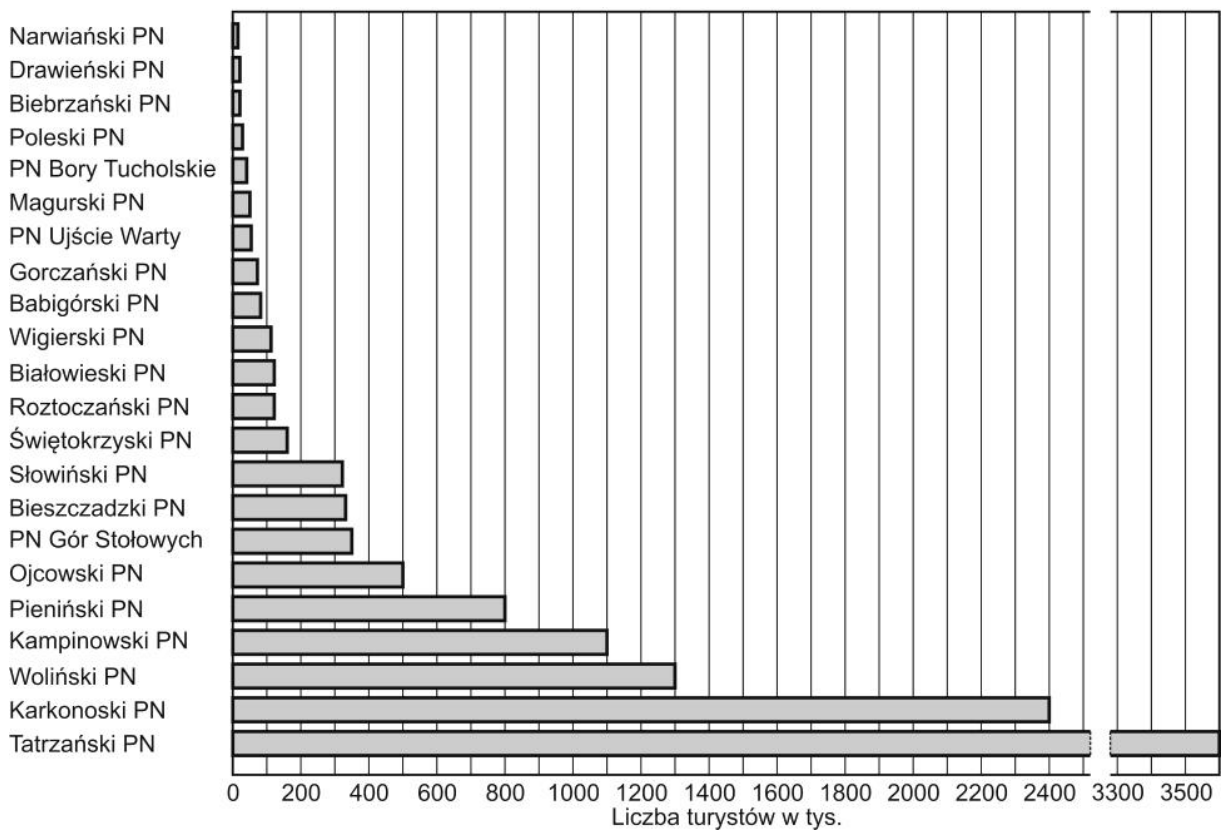

Rys. 1. Liczba turystów w polskich parkach narodowych w $2015 \mathrm{r}$.

Źródło: opracowanie własne na podstawie informacji na stronie internetowej Onet Podróże

Poza atrakcyjnością turystyczną na wybór parku narodowego mają wpływ także indywidualne upodobania, potrzeby i pobudki turystów, które często mają bardzo duże lub wręcz nadrzędne znaczenie w wybieraniu miejsca podróży turystycznej. Warto podkreślić, że niektóre obszary chronione, takie jak np. Tatrzański Park Narodowy, cieszą się już tak dużą popularnością i marką, że stają się wręcz obowiązkową destynacją każdego turysty.

Turystyka - jak wcześniej wspomniano - ma duże znaczenie dla obszarów chronionych oraz stanowi jeden z kluczowych aspektów ich działalności. Z jednej strony przynosi dużo korzyści, z drugiej stanowi niemałe zagrożenie dla chronionych zasobów środowiska. Także znalezienie odpowiedniego sposobu pogodzenia tych dwóch funkcji parku, tj. ochrony środowiska naturalnego i wykorzystywania jego obszaru przez człowieka, jest kluczowym zadaniem w ich działalności (Stasiak, 1997; Ziółkowski, 2006). 


\section{Turystyka na obszarach chronionych $\mathrm{w}$ programie studiów turystyka i rekreacja na Uniwersytecie Lódzkim}

Problematyka ochrony przyrody oraz turystyki na obszarach chronionych jest szeroko omawiana na kierunku studiów turystyka i rekreacja, prowadzonych na Wydziale Nauk Geograficznych Uniwersytetu Łódzkiego. Zakłada się, że uprawianie przez studentów turystyki na obszarach chronionych czy późniejsze podjęcie przez nich pracy w takich instytucjach, jak park narodowy lub krajobrazowy, wymaga przekazania im niezbędnej wiedzy oraz odpowiedniego przygotowania. Z tego powodu już od pierwszego roku studiów na różnych zajęciach studenci poznają środowisko geograficzne Polski i świata, formy ochrony przyrody obowiązujące w Polsce i na świecie oraz zasady ich funkcjonowania i organizacji turystyki na obszarach podlegających prawnej ochronie. Edukacja ta ma także wymiar praktyczny. Studenci pierwszego roku odbywają trzytygodniowe praktyki w parku narodowym lub krajobrazowym. Zapoznają się wtedy z tymi instytucjami „od kuchni”, stając się na ten czas ich integralną częścią. Pod okiem pracownika parku i jednocześnie opiekuna praktyk studenci uzyskują informacje na temat funkcjonowania i organizacji pracy w parku, sposobów ochrony zasobów jego środowiska oraz zasad ich udostępniania i użytkowania. Ponadto mają możliwość aktywnego udziału w różnego rodzaju pracach i zadaniach zleconych przez opiekuna praktyk, mogąc uczestniczyć np. w prowadzeniu badań diagnostycznych na obszarze parku. $W$ kolejnych latach edukacji przygotowywane są i bronione prace licencjackie oraz magisterskie, których tematyka dotyczy m.in. także turystyki na obszarach chronionych.

Jednym z przedmiotów znajdujących się w programie studiów na turystyce i rekreacji, a poruszających problematykę ruchu turystycznego na obszarach chronionych jest turystyczne i rekreacyjne użytkowanie obszarów chronionych. W roku akademickim 2018/2019 celem tego przedmiotu, na którego realizację składa się 10 godzin wykładów i 10 godzin ćwiczeń, było przekazanie wiedzy z zakresu:

- zasad, form i reżimu ochrony dziedzictwa przyrodniczego w Polsce i na świecie;

- sposobów i stopnia użytkowania tych obszarów przez turystykę i rekreację wraz ze wskazaniem jego konsekwencji.

Uzyskana przez studentów wiedza ma także służyć im do merytorycznego oraz problemowego ich przygotowania do odbycia praktyk za- 
wodowych w parku narodowym, parku krajobrazowym lub na innym chronionym obszarze (USOS UŁ).

$\mathrm{W}$ ramach tego przedmiotu omawiane były m.in. takie zagadnienia, jak: formy ochrony przyrody w Polsce i na świecie, uwarunkowania prawne ochrony przyrody, zrównoważony rozwój turystyki i jej formy na obszarach chronionych, tradycyjne i nowatorskie rozwiązania w rozwijaniu turystyki i rekreacji na obszarach chronionych czy zachowania i sylwetki turystów. Na ćwiczeniach studenci w praktyczny sposób wykorzystywali wiedzę zdobytą na wykładach, rozwiązując zadania dotyczące różnych aspektów turystyki i rekreacji na obszarach chronionych. Mieli możliwość prezentacji własnych doświadczeń oraz sądów, dotyczących turystycznego i rekreacyjnego użytkowania terenów chronionych.

Jednym z zadań (dla chętnych) było przygotowanie pracy pisemnej o wybranym obszarze chronionym. Temat pracy był sformułowany następująco: „Turystyka na obszarach chronionych w świetle własnych doświadczeń oraz wiedzy popularnej i naukowej". Zainteresowane osoby miały za zadanie przygotować tekst zawierający uzasadnienie wyboru obszaru, przedstawić ogólny opis jego geograficznego położenia, zaprezentować własne doświadczenia, krótkie sprawozdania zarówno ze zdobytej wiedzy popularnej, jak i naukowej oraz podsumowanie wyników własnych obserwacji czy przeglądu literatury.

Otrzymane od studentów prace na zadany temat należy uznać w większości za poprawne merytorycznie oraz ciekawe. Widać było, że niektórzy mieli trudność z przekazaniem własnych doświadczeń, ale wielu szeroko opisywało wybrane miejsca, swoje przeżycia i problemy, które zrobiły na nich największe wrażenie, $w$ tym także negatywne. Najczęściej poruszane zagadnienia $w$ tych pracach to spostrzeżenia związane z turystyką. Autorzy wskazywali miejsca cieszące się szczególną popularnością wśród turystów, ale zwracali także uwagę na negatywny wpływ turystyki na omawiany obszar, m.in. degradację środowiska. Opisywali czynniki, które zakłócały im eksplorację parków narodowych, np. zbyt dużą liczbę osób na szlakach oraz zachowania turystów, które ich zdaniem nie powinny mieć miejsca na tym obszarze: schodzenie ze szlaku, hałasowanie, niszczenie roślin, śmiecenie itp. Przedstawiali sposoby radzenia sobie z różnymi sytuacjami problemowymi. Proponowali rozwiązania, które ich zdaniem usprawniłyby pracę parku oraz przyczyniły się do poprawy stanu środowiska i zmniejszyły poziom negatywnego oddziaływania turystyki.

Wśród przygotowanych prac kilka było szczególnie interesujących, dlatego pojawił się pomysł opublikowania ich $\mathrm{w}$ monografii z serii Warsztaty 
z Geografii Turyzmu, który po zaprezentowaniu studentom na zajęciach dydaktycznych, został przyjęty z aplauzem. Spośród przedstawionych do oceny prac, wybrano cztery do przygotowania $\mathrm{w}$ formie notatek naukowych.

\section{Bibliografia}

Dobrzański, G., Dobrzańska, B., Kiełczewski, D. (1997). Ochrona środowiska przyrodniczego. Białystok: Wydawnictwo Ekonomia i Środowisko.

Dudek, A., Kowalczyk, A. (2003). Turystyka na obszarach chronionych - szanse i zagrożenia. Prace i Studia Geograficzne, 32, 117-140.

Harasimiuk, M., Sawicki, B. (red.) (2014). Rola obszarów chronionych w rozwoju edukacji, turystyki i gospodarki. Lublin: Uniwersytet Przyrodniczy.

Onet Podróże. Pobrane z: podroze.onet.pl (30.01.2019).

Radecki, W. (1987). Ochrona prawna obszarów przyrodniczo cennych. Kraków: Oddział Akademicki PTTK.

Stasiak, A. (1997). Turystyka w parkach narodowych - obszary konfliktów. Turyzm, 7 (2), 5-24.

Ustawa z dnia 16 kwietnia 2004 r. o ochronie przyrody. DzU 2004, nr 92, poz. 880.

Ziółkowski, R. (red.) (2006). Praktyczne aspekty rozwoju turystyki i rekreacji na obszarach przyrodniczo cennych. Białystok: Wydawnictwo Politechniki Białostockiej. 